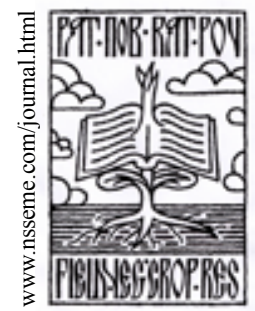

\title{
Climate Change Impact on Maize Yield in the Region of Novi Sad (Vojvodina)
}

\author{
Milena Jančić
}

received: 19 November 2013, accepted: 10 December 2013

published online: 21 January 2014

(c) 2013 IFVC

doi: $10.5937 /$ ratpov50-4941

\begin{abstract}
Summary: PDSSAT 4.0 is a crop model commonly used to quantify the climate change impact on agriculture production. The model objective is to predict the duration of growth, average growth rates and the amount of assimilate partitioned to the economic yield components of the plant. A model structure is comprehensively described in this paper. The input parameters were used from NSSC 640 maize nine year field experiment from Rimski Šančevi in Novi Sad and climate data were given by Republic Hydrometeorology Service of Serbia (RHSS) for current climate, as well as for 2030 and 2050 using three climate models (ECHAM5, HadCM3 and NCAR-PCM) under two scenarios (A1B SRES and A2 SRES). DSSAT 4.0 maize yield simulations were performed for period 1971-2000, as well as for 2030 and 2050. The change in yield for 2030 and 2050 was calculated relative to 1971-2000. The results showed lower yields in 2030 and 2050, especially in rainfed conditions.
\end{abstract}

Key words: climate, climate change, crop modelling, DSSAT 4.0, maize, yield simulation

\section{Introduction}

During the last decades of the twentieth century, a higher level of awareness has arisen about the impact of global climate change on the world economy (Houghton. 1996). The most vulnerable part of economy is agriculture and key focus of current research is to predict future changes in climate and suggest how these changes will curtail current agricultural technology at individual locations (Eitzinger et al. 2010). Every country monitors changes to make adaptation options and decisions in agrotechnology.

Serbia is a developing country with favourable agroecological conditions, which has made agricultural production traditionally important part of the national economy. According to the Statistical Office of the Republic of Serbia (STAT 2006), the agriculture accounts for about $11.5 \%$ of gross value added in 2004 .

The previous climate studies in Vojvodina region included comparative analyses of the current weather conditions (1985-2005) and expected for 2040, 2080 and its impacts on agrometeorological conditions for some crops (Lalic

M. Jančić

University of Novi Sad, Faculty of Agriculture, 8 Trg Dositeja Obradovića, 21000 Novi Sad

e-mail: orhideja007@gmail.com et al. 2011). The impact of climate changes on winter wheat yield was quantified with Sirius crop model (Lalic et al. 2007, Lalic et al. 2011). Obtained results gave a possibility in making adaptation measures (Lalic et al. 2011, Mihailović et al. 2010). The succeeding research was focused on identification of agroclimatic parameters which in the best possible way point out the effects of climate change and variability on winter wheat yield change in the Pannonian lowland, with respect to different $\mathrm{CO}_{2}$ concentrations and soil types (Lalic et al. 2012).

Maize grain has significant place in plant production in Serbia and it participates with $68.4 \%$ in whole plant production. Maize has the biggest sown area of all agricultural crops: $1,235,000$ ha and maize production was $7,207,191$ $\mathrm{t}$ in 2010 . In economic aspect, maize grain export was $3.42 \%$ and valued in external trade balance with $334,923,000$ USD which was $1.18 \%$ of national GDP (STAT 2010). Maize production is organised mainly in non-irrigated conditions.

Acknowledgements:

This research was funded by the Serbian Ministry of Education, Science and Technological Development under the project No. III 43007 "Research of climate changes and their impact on environment. Monitoring of the impact, adaptation and moderation" for 2011-2014. Author is grateful to Prof. Dr. Branislava Lalić and Prof. Dr. Dragutin T. Mihailović for their suggestions. 
There is a need to estimate how climate changes may affect maize yield under climate change conditions.

Climate models and crop models are used to quantify the climate change impact on crop growth, dynamic and yield. It is possible to estimate the limits and vulnerability for crop production in climate change conditions, based on the model results.

The scientific community has successfully evaluated and validated DSSAT crop model for maize varieties in various regions (Samuhel et al. 2007, Maytin et al. 1995); potential adaptation measures estimated with DSSAT crop model were used by Wang et al. (2011), evapotranspiration rates by Tao et al. (2010), maize productivity and water use by Tao et al. (2010), and earlier sowing dates and new varieties by Kapetanaki et al. (1996). The main goal of this study was to quantify climate change effect on maize production using DSSAT 4.0 model. A crop model was tested and validated in maize production for Novi Sad medium late maize hybrid NSSC 640 in rainfed and irrigated conditions for current climate 1971-2000 and under climate changes for 2030 and 2050. The agrotechnology data were used from experimental field of Institute of Field and Vegetable Crops in the period 1997-2005 (Pejic et al. 2009) and data for current climate were assimilated by Republic Hydrometeorology Service of Serbia (RHSS). For expected climate conditions, the GCM results were obtained from the following climate models: ECHAM5, HadCM3 and NCAR-PCM and downscaled with Met \& Roll weather generator.

This paper presents: (a) DSSAT 4.0 calibration and validation results and (b) calculated relative change in yield for NSSC 640 maize hybrid for
2030 and 2050 in rainfed and irrigated conditions. The period 1971-2000 was considered as baseline period in the analysis.

A crop model results may indicate the limits and vulnerability for certain crop production in climate change conditions. This information will help both producers and plant breeders to select appropriate adaptation measures and to make long-term plans in agriculture for high and stable yield.

\section{Materials and Methods}

\section{DSSAT 4.0 Model Description}

DSSAT 4.0 model was developed as a result of IBSNAT project (International Benchmark Sites Network for Agrotechnology Transfer project) to simulate biological crop demands and the most effective use of current and expected climate and soil resources (Tsuji et al. 1998). Model contains submodules that describe atmosphere-soil-crop interaction. Functional scheme of DSSAT 4.0 model consists of input data, submodules and output results (Fig. 1).

Input Data. Minimum data set was defined in 1984 and periodically amended until 1988 (IBSNAT 1984, IBSNAT 1986, IBSNAT 1988, IBSNAT 1989). The data refer to meteorological and soil conditions, genetic coefficients and applied agrotechnology (Fig. 1).

Meteorological Conditions. For current climate conditions, daily weather data that included meteorological element values (maximum temperature, minimum temperature, precipitation, evaporation, solar radiation and wind speed) were observed at weather station Rimski Sančevi for

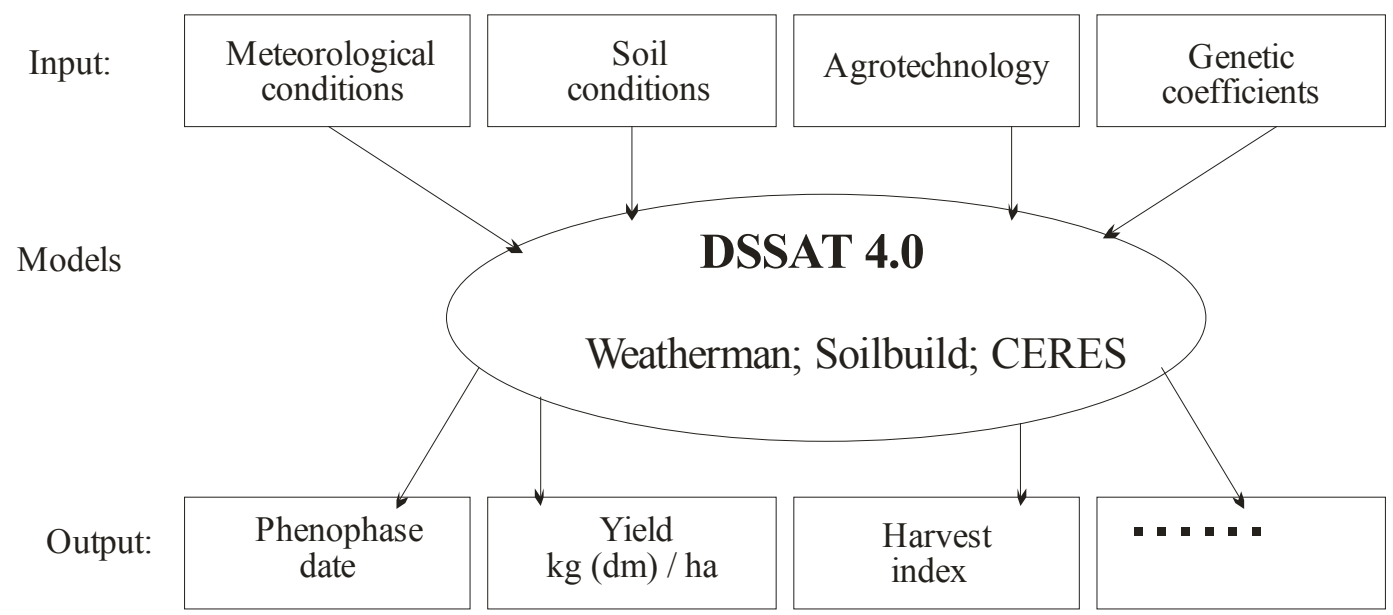

Figure 1. DSSAT 4.0 functional scheme 
period 1971-2000, which were given by the RHSS. For expected climate conditions in Novi Sad region, daily meteorological data were obtained using three global climate models ECHAM5 (Roeckner et al. 2003), HadCM3 (Gordon et al. 2000) and NCAR-PCM (Washington et al. 2000). The simulations were performed for the so called „pessimistic“ (SRES-A2) and "realistic“" (SRES-A1B) scenario for greenhouse gas (GHG) emission for 2030 and 2050. The first step in an assessment of climate change impacts on agriculture is downscaling of climate model outputs. In this paper, the result regionalisation was performed by Met \& Roll weather generator (Dubrovsky 1996, 1997). In all simulations, $\mathrm{CO}_{2}$ concentration was $330 \mathrm{ppm}$. This approach is denoted as 'climate change only' in literature of crop simulations.

\section{Climate Conditions}

Table 1. Chernozem mechanical characteristics particle content (\%) (Ćirić 2008)

$\begin{array}{lllll}\begin{array}{l}\text { Depth } \\ (\mathrm{cm})\end{array} & \begin{array}{l}\text { Coarse } \\ \text { sand }\end{array} & \begin{array}{l}\text { Fine } \\ \text { sand }\end{array} & \text { Loam } & \text { Clay } \\ 0-30 & 0.8 & 35.9 & 35.8 & 27.5 \\ 30-53 & 1.3 & 37.8 & 34.3 & 26.5 \\ 53-88 & 10.7 & 44.2 & 28.3 & 16.7\end{array}$

Table 2. Chernozem chemical characteristics

$\begin{array}{llll}\begin{array}{l}\text { Depth } \\ (\mathrm{cm})\end{array} & \begin{array}{l}\mathrm{pH} \text { in } \\ \mathrm{H}_{2} \mathrm{O}\end{array} & \text { OrganicC }(\%) & \begin{array}{l}\text { Nitrate } \\ (\%)\end{array} \\ 0-30 & 6.9 & 1.5 & 0.2 \\ 30-53 & 7.9 & 0.9 & 0.1 \\ 53-88 & 8.2 & 0.6 & 0.1\end{array}$

Current Climate (1971-2000). In Novi Sad the temperature and precipitation were observed in two periods: April-September (AS) growing season and June-July-August (JJA), which is critical period for maize water demands. In AS period, observed temperature was $17.8^{\circ} \mathrm{C}$ with $360.1 \mathrm{~mm}$ of precipitation. During JJA period, temperature was $20.6^{\circ} \mathrm{C}$ with $206.1 \mathrm{~mm}$ of precipitation.

Expected Climate (2030 and 2050). The results from climate model ECHAM5 under A2 scenario predicted that temperature in 2030 for AS is expected to be $1.3^{\circ} \mathrm{C}$ higher and $1.5^{\circ} \mathrm{C}$ higher for JJA period, while the precipitation for these periods (AS) may be 15\% lower and 33\% lower in JJA than in 1971-2000. In 2050 ECHAM5 under A2 scenario predicted temperatures were $2.5^{\circ} \mathrm{C}$ higher in AS period and $3.1^{\circ} \mathrm{C}$ higher in JJA, while the precipitation for AS period is expected to be $26 \%$ lower and $46 \%$ lower than in 1971 2000 .

Soil Conditions. The soil type and characteristics (mechanical and chemical) were assimilated from Ćirić (2008). The values of parameters used in simulations are given in Tables 1 and 2 .

Agrotechnology. The experimental field was managed at the Institute of Field and Vegetable Crops in Novi Sad in a nine-year period (Pejic et al. 2009). In the first experimental year, the sowing was performed on April 20, 1997 with NSSC 640 medium season maize variety. In this trial NSSC 640 was sown on $35 \mathrm{~m}^{2}$ field area, in block system in rows with density of 5.7 plants/ $\mathrm{m}^{2}$ (57.143 plants/ha), on $5 \mathrm{~cm}$ depth at $70 \mathrm{~cm}$ distance between rows and $25 \mathrm{~cm}$ between plants in a row. Mineral fertilizers were applied in fall $(135 \mathrm{~kg} / \mathrm{ha}$ of $\mathrm{N}, 135 \mathrm{~kg} / \mathrm{ha}$ of $\mathrm{P}$ and $175 \mathrm{~kg} /$ ha of $\mathrm{K}$ ) and spring (46 kg/ha of $\mathrm{N}$ with urea).

Table 3. Genetic coefficients of maize

Genetic coefficients

Values

Thermal time from seedling emergence to the end of the juvenile stage (degree days $220.0^{\circ} \mathrm{C}$ above the base temperature of $8^{\circ} \mathrm{C}$ in the juvenile stage) (P1)

Photoperiod sensitivity associated with delayed growth under the unfavourable longdaylight condition (P2)

Thermal time from silking to physiological maturity in degree days above the base temperature of $8^{\circ} \mathrm{C}$ in mature stage (P5)

Potential maximum number of kernels per plant (G2)

Kernel filling rate under optimum conditions (G3)

Interval in thermal time between successive leaf tip appearances in degree days above

0.400

the base temperature of $8^{\circ} \mathrm{C}$ (PHINT)

$980.0{ }^{\circ} \mathrm{C}$

$800.0 \mathrm{kernel} / \mathrm{ear}$ $8.50 \mathrm{kernel} / \mathrm{day}$ 38.90 
Standard agronomic practices for maize growing were applied. The experimental aim was to test sprinkler irrigation method and its effect on maize yield, with $180 \mathrm{~mm}$ of water supplied per vegetation period. The yield values differences between rainfed and irrigated maize field were monitored.

Five genetic coefficients were defined in maize simulations (Tab. 3). These coefficients are necessary input data because they describe varieties phenological characteristics. They were given calculating the temperature sum for each vegetation phenophase (Ritchie et al. 1993).

Genetic coefficients were assimilated from DSSAT 4.0 crop model for medium late maize, as NSSC 640. DSSAT 4.0 crop model contains three submodules: meteorological module (Weatherman), soil module (Soilbuild) and crop simulation module (CERES). In meteorological module (Weatherman), observed meteorological element values and values from climate models were input data, where they were classified and saved in special files necessary for further crop simulations. Soil module contained observed soil characteristics as input data. After processing data, soil type for further crop modelling was defined. Soil nitrogen quantity and organic carbon fertility were also necessary input data.

Production of cereal crops which may be simulated in DSSAT 4.0 by CERES crop model include maize, wheat, barley, millet, sorghum and rice. A feature of this model is its capability to include cultivar specific information that makes possible prediction of the cultivar variations in plant ontogeny and yield component characteristics and their interaction with weather and soil. CERES calculates vegetation phase, growth rate and biomass partitioning in plant parts. These processes are dynamic and affected by genetic coefficients and environmental conditions. Biomass growth is calculated using the radiation use efficiency approach; biomass production is partitioned between leaves, stems, roots, ears and grains. The proportion partitioned to each growing organ is determined by the stage of development and general growing conditions. The crop yield is defined as a product of the grain numbers per plant times the average kernel weight at physiological maturity. The grain numbers are calculated from the above ground biomass growth during the critical stage in the plant growth cycle for a fixed thermal time before anthesis. The grain weight is calculated as a function of cultivar specific optimum growth rate multiplied by the duration of grain filling (Tsuji et al. 1998). Based on genetic coefficients, environmental conditions and field experiment data, it is possible to calibrate crop model.

\section{Results and Discussion}

\section{Model Calibration and Validation}

The first step in crop model use is its calibration and validation. Using input data, model is calibrated for NSSC 640 hybrid in rainfed and irrigated conditions adjusting genetic coefficients to get the similar simulated yield values and maturity duration to observed values from experimental field at the Institute of Field and Vegetable Crops at Rimski Šančevi (Tab. 4 and Tab. 5).

The relative deviation between simulated and observed yield was $37.1 \%$ in rainfed experiment field (Tab. 4). The highest (relative) deviation was for 2000, 2002, 2003 and 2004 (Fig. 2) in which the number of dry days was above long-

Table 4. Validation of grain yield ( $t / h a)$ for NSSC 640 in rainfed conditions at Rimski Sančevi for 1997-2005 period

\begin{tabular}{|l|l|l|l|}
\hline Year & Observed & Simulated & $\begin{array}{l}\text { Rel. } \\
\text { deviation } \\
\text { in yield } \\
(\%)\end{array}$ \\
\hline 1997 & 12.2 & 10.8 & 10.8 \\
\hline 1998 & 9.2 & 10.1 & 10.5 \\
\hline 1999 & 10.5 & 11.9 & 13.7 \\
\hline 2000 & 8.0 & 0.9 & 88.7 \\
\hline 2001 & 9.6 & 8.1 & 15.9 \\
\hline 2002 & 10.2 & 2.4 & 76.5 \\
\hline 2003 & 9.6 & 2.7 & 71.9 \\
\hline 2004 & 10.5 & 2.4 & 76.7 \\
\hline 2005 & 13.8 & 11.4 & 17.4 \\
\hline Aver. & 10.4 & 6.8 & 37.1 \\
\hline
\end{tabular}

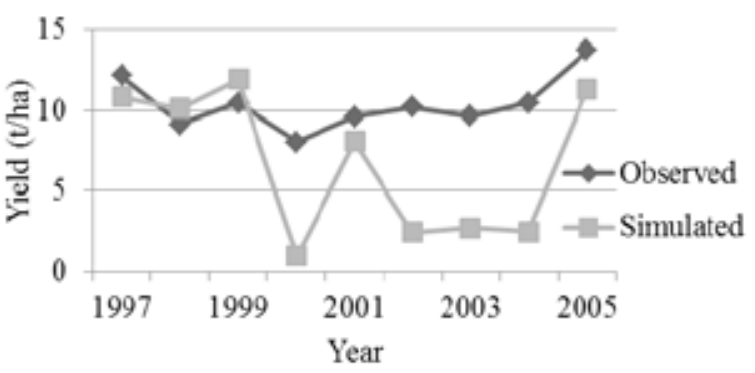

Figure 2. Simulated and observed grain yield of hybrid NSSC $640(\mathrm{t} / \mathrm{ha})$ in rainfed conditions at Rimski Šančevi for 1997-2005 
Table 5. Validation of grain yield ( $t / h a)$ for NSSC 640 in irrigated conditions at Rimski Śančevi for the 1997-2005 period

\begin{tabular}{|l|l|l|l|}
\hline Year & Observed & Simulated & $\begin{array}{l}\text { Rel. } \\
\text { deviation } \\
\text { in yield } \\
(\%)\end{array}$ \\
\hline 1997 & 14.1 & 13.7 & 2.6 \\
\hline 1998 & 10.3 & 14.1 & 37.1 \\
\hline 1999 & 11.4 & 13.5 & 17.7 \\
\hline 2000 & 13.5 & 6.7 & 50.1 \\
\hline 2001 & 10.8 & 11.1 & 3.2 \\
\hline 2002 & 13.6 & 10.6 & 21.8 \\
\hline 2003 & 13.5 & 10.4 & 23.1 \\
\hline 2004 & 13.0 & 8.3 & 35.9 \\
\hline 2005 & 14.2 & 13.7 & 3.8 \\
\hline Aver. & 12.7 & 11.3 & 8.8 \\
\hline
\end{tabular}

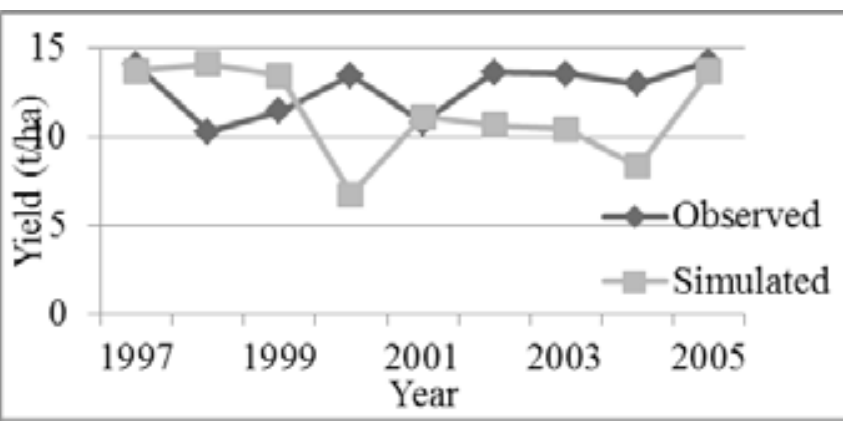

Figure 3. Simulated and observed grain yield for NSSC 640 ( $\mathrm{t} / \mathrm{ha})$ in irrigated conditions at Rimski Šančevi for the period 1997-2005 term average in growing season. This significant difference between simulated and observed yield values is a consequence of model inability to simulate the plant reaction to stress in extreme conditions, such as high variations in daily air temperature and precipitation sum in short time intervals (Lalić et al. 2011). If the yield values in dry years were excluded from calculation (calibration), the relative deviation in yield will be $4 \%$ in rainfed conditions.

In irrigated conditions (Tab. 5), relative deviation between simulated and observed yield was $8.8 \%$. The highest relative deviation was given for 2000, 1998 and 2004 (Fig. 3) in irrigated conditions, because those were the years with extreme dry conditions. If the yield values in dry years are excluded from calculation (calibration), the relative deviation in yield will be $5.1 \%$ in rainfed conditions.

\section{The expected maize yield in 2030 and 2050}

Using current agrotechnology, soil characteristics data and synthesized weather series for three GCMs (H - ECHAM5, M - HadCM3, $\mathrm{N}-\mathrm{NCAR}$ PCM) under two scenarios (A1B and A2) the yield was projected for 2030 and 2050. The yield results were obtained in rainfed and irrigated conditions. In Tables 6 and 7, change in yield for 2030 and 2050 calculated relative to the baseline yield 1971-2000 is presented.

If we analyse the obtained results, all GCMs and both scenarios gave significant decrease in yield for 2030 and 2050. Using DSSAT - CERES model, in rainfed conditions, the maize yield was significantly lower (up to $40 \%$ in 2030 and $58 \%$ in 2050$)$ than in irrigated conditions $(20 \%$ in 2030 and $31 \%$ in 2050). In expected climate, it is concluded that irrigation method has to

Table 6. Relative yield change (\%) in 2030 and 2050 in rainfed conditions using three GCMs (H ECHAM5, M - HadCM3, N - NCAR PCM) under two scenarios (A1B and A2)

\begin{tabular}{|c|c|c|c|c|c|c|c|c|c|c|c|}
\hline 2030 & & & & & & 205 & & & & & \\
\hline A1B & & & A2 & & & A1H & & & A2 & & \\
\hline $\mathrm{H}$ & $\mathrm{M}$ & $\mathrm{N}$ & $\mathrm{H}$ & $\mathrm{M}$ & $\mathrm{N}$ & $\mathrm{H}$ & $\mathrm{M}$ & $\mathrm{N}$ & $\mathrm{H}$ & $\mathrm{M}$ & $\mathrm{N}$ \\
\hline-36 & -29 & -23 & -40 & -33 & -27 & -53 & -46 & -38 & -58 & -52 & -43 \\
\hline
\end{tabular}

Table 7. Relative yield change (\%) in 2030 and 2050 in irrigated conditions using three GCMs (H ECHAM5, M - HadCM3, N - NCAR PCM) under two scenarios (A1B and A2)

\begin{tabular}{llllllllllll}
2030 & \multicolumn{10}{c}{2050} \\
\hline A1B & & & A2 & \multicolumn{10}{c}{ A1B } & & & A2 & & \\
$\mathrm{H}$ & $\mathrm{M}$ & $\mathrm{N}$ & $\mathrm{H}$ & $\mathrm{M}$ & $\mathrm{N}$ & $\mathrm{H}$ & $\mathrm{M}$ & $\mathrm{N}$ & $\mathrm{H}$ & $\mathrm{M}$ & $\mathrm{N}$ \\
-17 & -14 & -8 & -20 & -17 & -10 & -27 & -25 & -15 & -31 & -31 & -18 \\
\hline
\end{tabular}


be adapted to keep stable and high yield. After detailed analysis, two used scenarios (A1B, A2) gave similar yield results for one integration period. In a comparison of three climate model results, there were no differences between ECHAM5 and HadCM3 and slightly differences between HadCM3 and NCAR PCM in 2050. Only, the ECHAM5 and NCAR PCM climate models gave differences in yield results ranging from 9 to $15 \%$.

The lowest yield for future conditions in rainfed and irrigated conditions was predicted by ECHAM 5 model under A2 scenario in both 2030 and 2050 integration period.

\section{Conclusions}

DSSAT 4.0. crop model structure was described in detail, calibrated and validated for NSSC 640 medium late maize. The yield results are necessary for adaptation measures in current agrotechnology to keep high and stable yield in expected climate conditions. In rainfed conditions, very significant decrease in yield up to $58 \%$ (ECHAM5, A2) in 2030 and up to $40 \%$ (ECHAM5, A2) in 2050 was predicted. In irrigated conditions lower yield up to $20 \%$ (ECHAM5, A2) in 2030 and up to $31 \%$ (ECHAM5, A2) in 2050 was predicted. The expected higher temperatures and lower precipitation during AS and JJA period will impact dynamics in vegetation phases, as well as in yields. Based on climate data, soil water analysis and maize water demands, the necessary water quantity for stable maize yield will be calculated. All relative changes in yield results and expected climate conditions show lower precipitation in vegetation period and problem in soil water hold capacity. The control and better water holding capacity may be reached with modifications in current agrotechnology with introducing adaptation measures: 1) earlier sowing (sowing should be earlier, how the soil water reserves will be better used in germination and emergence phenophases); 2) new genotypes tolerant to drought stress and 3) occasional shallow tillage (lower soil water losses); 4) implementation of irrigation system and method (in summer vegetation phases, frequent in heat days with maximum daily temperature higher than $30^{\circ} \mathrm{C}$ is expected, which could affect shorter vegetation duration and smaller yield).

\section{References}

Ćirić, V. (2008). Vodno-fizička svojstva černozema, kao činilac plodnosti u proizvodnji kukuruza. Novi Sad: Univerzitet u Novom Sadu, Poljoprivredni fakultet.

Dubrovsky, M. (1996). Met\&Roll: the stochastic generator of daily weather series for the crop growth model. Meteorol Zpravy, 49, 97-105.

Dubrovsky, M. (1997). Creating Daily Weather Series with Use of the Weather Generator. Environmetrics, 8(5), 409-424.

doi:10.1002/(SICI)1099-095X(199709/10)8:5<409::AIDENV.

Eitzinger, J., Orlandini, S., Stefanski, R., \& Naylor, R.E.L. (2010). Climate change and agriculture: introductory editorial. $\mathrm{J} \mathrm{Agr}$ Sci, 148, 499-500.

Gordon, C., Cooper, C., Senior, C.A., Banks, H., Gregory, J.M., Johns, T.C., ... Wood, R.A. (2000). The simulation of SST, sea ice extents and ocean heat transports in a version of the Hadley Centre coupled model without flux adjustments. Climate Dynamics, 16, 147-168.

Houghton, J.T., Filho, M.L.G., Callander, B.A., Harris, N., Kattenberg, A., \& Maskell, K. (1996). Climate Change 1995. In The Science of Climate Change. Cambridge: Cambridge University Press.

International Benchmark Sites Network for Agrotechnology Tranfer (IBSNAT). (1984). Experimental design and data collection procedures for IBSNAT. The minimum data set for systems analysis and crop simulation. Technical Report 1. Honolulu, Hawaii, USA: Department of Agronomy and Soil science, University of Hawaii.

International Benchmark Sites Network for Agrotechnology Transfer (IBSNAT). (1986). Experimental design and data collection procedures for IBSNAT: The minimum data set for systems analysis and crop simulation. Technical Report 1, 2nd ed. Honolulu, Hawaii, USA: Department of Agronomy and Soil science, University of Hawaii.

International Benchmark Sites Network for Agrotechnology Tranfer (IBSNAT). (1988). Experimental design and data collection procedures for IBSNAT: The minimum data set for systems analysis and crop simulation. Technical Report 1, 3rd ed. Honolulu, Hawaii, USA: Department of Agronomy and Soil science, University of Hawaii.

International Benchmark Sites Network for Agrotechnology Tranfer (IBSNAT). (1989). Decision support system for agrotechnology transfer $v 2.1$ (DSSAT v 2.1).. Honolulu, Hawaii, USA: Department of Agronomy and Soil Science, University of Hawaii.

Kapetanaki, G., \& Rosenzweig, C. (1997). Impact of climate change on maize yield in central and northern Greece: A simulation study with CERES-Maize. Mitigation and Adaptation Strategies for Global Change, 1(3), 251-271. doi:10.1007/ BF00517806.

Lalić, B., Panković, L., Mihailović, D.T., Malešević, M., \& Arsenić, I. (2007). Modeli biljne proizvodnje i njihova upotreba u prognozi dinamike vegetacije. Ratar. Povrt, 44(1), 317-323.

Lalić, B., Mihailović, D.T., \& Podraščanin, Z. (2011). Buduće stanje klime u Vojvodini i očekivani uticaj na ratarsku proizvodnju. Ratar. Povrt. 48(2), 403-418. doi:10.5937/ratpov1102403L

Lalic, B., Eitzinger, J., Mihailovic, D.T., Thaler, S., \& Jancic, M. (2012). Climate change impacts on winter wheat yield change - which climatic parameters are crucial in Pannonian lowland.J Agr Sci, doi:10.1017/S0021859612000640. 
Lalic, B., Eitzinger, J., Thaler, S., Nejedlik, P., Kazandjiev, V., Vucetic, V., ... Eckersten, H. (2011). Using results of modelled yield deviation and indices of weather extremes towards a better yield assessment - current state of research. In: Proc Int Conf Current Know Climate Ch Imp Agr Forest Eu, 1, Topolcianki, Slovačka.

Maytin, C.E., Acevedo, M.F., Jaimez, R., Andressen, R., Harwell, A.M., Robock, A., \& Azocar, A. (1995). Potential effects of global climatic change on the phenology and yield of maize in venezuela. Climatic Change, 29(2), 189-211. doi:10.1007/ BF01094016

Mihailovic, D.T., Lalic, B., Koci, I., Malesevic, M., Jevtic, R., Keserovic, Z., \& Jancic, M. (2010). Vulnerability assessment, climate change impacts and adaptation measures - Agriculture. In D. Bozanic \& M. Gasperic (Eds.), Initial National Communication of the Republic of Serbia under the United Nations Framework Convention on Climate Change. (p. 14). Serbia: Ministry of Environment and Spatial Planning.

Pejić, B., Bošnjak, Đ., Mačkić, K., Stričević, R., Simić, D., \& Drvar, A. (2009). Osetljivost kukuruza (Zea mays L.) na deficit vode u zemljištu u određenim podperiodima vegetacije. Letopis naučnih radova Poljoprivrednog fakulteta, 33(1), 155-166.

Roeckner, E., Bäuml, G., Bonaventura, L., Brokopf, R., Esch, M., Giorgetta, M., .. Tompkins, A. (2003). The atmospheric general circulation model ECHAM-5: Model description. Rep. No., 349. Hamburg, Deutschland: Max-Planck-Institut fur Meteorologie.

Ritchie, J.T. (1993). Genetic specific data for crop modelling. Systems approaches for agricultural development. Dordrecht, Netherlands: Kluwer Academic Publishers.

Samuhel, P., \& Šiška, B. (2007). Parametrization of Crop Simulation Model "CERES-MAIZE" in Nitra -Dolna Malanta. J Environ Eng Land Manag, 15(1), 25-30.

Republički zavod za statistiku (2006). Statistički godišnjak Republike Srbije. Beograd.

Republički zavod za statistiku (2010). Statistički godišnjak STAT. Beograd.

Tao, F., \& Zhang, Z. (2010). Impacts of climate change as a function of global mean temperature: maize productivity and water use in China. Climatic Change, 105(3-4), 409-432.

Tsuji, G., Hoogenboom, G., \& Thornton, P. (1998). Understanding options for agricultural production. Dordrecht, Netherlands: Kluwer Academic Publisher.

Wang, M., Yinpeng, L., Ye, W., Bornman, J., \& Yan, X. (2011). Effects of climate change on maize production and potential adaptation measures: a case study in Jilin Province, China. Climate Res, 46, 223-242.

Washington, W.M., Weatherly, J.W., Meehl, G.A., Semtner, J.A.J., Bettge, T.W., Craig, A.P., . . Z Zhang, Y. (2000). Parallel climate model (PCM) control and transient simulations. Climate Dynamics, 16(10-11), 755-774. doi:10.1007/ s003820000079.

\title{
Uticaj klimatskih promena na prinos kukuruza u regionu Novog Sada (Vojvodina)
}

\author{
Milena Jančić
}

Sažetak: SDSSAT 4.0 je model biljne proizvodnje čija je namena predviđanje i kvantifikovanje uticaja klimatskih promena na poljoprivrednu proizvodnju. U radu je posvećena pažnja prikazu strukture i funkcionalnosti modela. Kao ulazni podaci upotrebljeni su rezultati devetogodišnjih ispitivanja hibrida kukuruza NSSC 640 na eksperimentalnom polju Instituta za ratarstvo i povrtarstvo na Rimskim šančevima u Novom Sadu i meteorološki podaci Republičkog hidrometeorološkog zavoda Srbije. Za buduće stanje klime korišćeni su izlazi iz tri klimatska modela (ECHAM5, HadCM3 and NCAR-PCM) i dva scenarija za 2030. i 2050. godinu. DSSAT 4.0 simulacije prinosa dobijene su za period 1971-2000, 2030. i 2050. godinu. Izračunata je relativna promena prinosa kukuruza za očekivane klimatske uslove 2030. i 2050. godine u odnosu na period 1971-2000, kao kvantitativni pokazatelj uticaja klimatskih promena na prinos i proizvodnju kukuruza. Analiza rezultata relativne promene prinosa zrna ukazuje na očekivano značajno opadanje prinosa u odnosu na period 1971-2000, što je naglašeno u uslovima bez navodnjavanja.

Ključne reči: DSSAT 4.0, klima, klimatska promena, kukuruz, model biljne proizvodnje, simulacija prinosa 